\title{
MEMOTIVASI PETANI DALAM PENGEMBANGAN PADI ORGANIK DI KECAMATAN SUKOLILO KABUPATEN PATI
}

\section{MOTIVATING THE RICE FARMERS IN DEVELOPING ORGANIC RICE IN SUKOLILO SUBDISTRICT PATI REGENCY}

\author{
Sutrisno \\ Kantor Penelitian dan Pengembangan Kabupaten Pati \\ Email: trisno_1201@yahoo.com
}

Naskah Masuk: 23 September 2016 Naskah Revisi: 30 September 2016 Naskah Diterima: 7 Oktober 2016

\begin{abstract}
The essence of organic farming is 'back to the nature'. This paper aims to identify the farmers' motivation and the management strategy of organic rice in Sukolilo Subdistrict Pati District. This paper concludes: 1) the growth of farmers' motivation to cultivatethe land with organic farming needs the strengthening. The positive reinforcement might change the behaviour continuously;2) The development of organic farming systems in Sukolilo Subdistrict Pati Regency generally dependson the government's policy framework on agriculture. Therefore, the organic rice development programmust have the vision to strengthen of Indonesian agriculture. Moreover, it should be environment-based as the basic for national independency in the free-market era. The mission should be able to developthe farmer's bargaining position in the development of agricultural program through a community-based approach, so that the development of the agricultural sector is able to meet the international market demand throughdirected, controlled and sustained program planning.
\end{abstract}

Keywords : motivation, organic rice, farmer

\begin{abstract}
ABSTRAK
Pada hakekatnya pertanian organik adalah back to nature. Tulisan ini bertujuan untuk mengindentifikasi motivasi petani dan strategi pengembangan tanaman padi organik di Kecamatan Sukolilo Kabupaten Pati. Tulisan ini menyimpulkan: 1) Tumbuhnya motivasi petani dalam mengelola lahan dengan sistem pertanian organik perlu diberikan penguatan. Dengan penguatan atau rangsangan yang positif, petani akan mengubah perilaku secara kontinyu atau terus menerus. 2) Kegiatan pengembangan sistem pertanian organik di Kecamatan Sukolilo Kabupaten Pati secara umum tidak terlepas dari kerangka kebijakan pemerintah pada sektor pertanian. Oleh karena itu kegiatan pengembangan padi organik harus memiliki visi membangun kekuatan pertanian Indonesia, berwawasan lingkungan sebagai basis kemandirian bangsa menghadapi era pasar bebas. Misi yang diemban juga hendaknya mampu membangun posisi tawar masyarakat tani dalam pengembangan kegiatan pertanian melalui pendekatan berbasis masyarakat, sehingga pengembangan sektor pertanian mampu memenuhi keinginan pasar internasional, dalam perencanaan program yang terarah, terkendali dan berkelanjutan.
\end{abstract}

Kata kunci: motivasi, padi organik, petani 


\section{PENDAHULUAN}

Paradigma pembangunan sekarang bukan lagi mengarah pada pembangunan berorentasi proyek, tetapi hakekat sesungguhnya dari pembangunan adalah pemecahan masalah yaitu masalah yang dihadapi oleh rakyat selama ini. Jika permasalahan yang dihadapi rakyat selama ini memperoleh pemecahan yang memadai, maka sedikit demi sedikit namun pasti kesejahteraan rakyat akan terurai semakin meningkat. Sementara masyarakat miskin jika dilakukan identifikasi kebutuhan, maka kebutuhan yang dipandang bersifat mendesak dan perlu mendapat prioritas pelayanan adalah kebutuhan akan bahan pangan. Oleh karena itu, pemerintah bertanggung jawab pada rakyatnya untuk dapat memperoleh bahan pangan (produk pertanian) yang cukup, berkualitas, sehat dan ramah lingkungan.

Kabupaten Pati dengan luas wilayah $150.368 \mathrm{Ha}$ yang terdiri dari 58.749 Ha $(39,08 \%)$ lahan sawah dan $91.619 \mathrm{Ha}(60,92 \%)$ lahan bukan sawah. Termasuk lahan bukan sawah ini dimanfaatkan untuk perkebunan dan perikanan darat. Sementara Kecamatan Sukolilo sebagai lokasi pengamatan dalam tulisan ini merupakan wilayah sentra tanaman padi dengan luas lahan sawah berpengairan teknis $5.817 \mathrm{Ha}$ $(15,86 \%)$ adalah potensi untuk pengembangan padi organik yang selama ini belum dilakukan. Jumlah penduduk Kabupaten Pati mencapai 1.225.594 jiwa, sementara penduduk Kecamatan Sukolilo mencapai 88.362 jiwa $(7,21 \%)$ dengan mata pencahariannya bervariasi dan sebagian besar bekerja disektor pertanian (secara umum) (BPS Kab. Pati 2014). Kontribusi sektor pertanian pada produk domestik regional bruto (PDRB) Kabupaten Pati masih tetap yang terbesar dibanding sektor-sektor lainnya yaitu sekitar 40\% (BPS Kab. Pati, 2014).
Data tersebut menunjukkan bahwa tulang punggung kehidupan masyarakat Kabupaten Pati masih didominasi pada sektor pertanian. Jumlah orang yang terlibat dalam kegiatan tersebut mencapai ribuan, sehingga dampaknya bagi perekonomian dan stabilitas sosial politik akan sangat signifikan.

Akhir-akhir ini disinyalir peningkatan produktivitas dan kualitas pertanian di Kabupaten Pati mendapat tantangan berat dengan adanya gejala pelandaian produktivitas serta menurunnya kualitas hasil pertanian terutama padi (Sutrisno, 2009). Untuk meraih kembali produktivitas dan kualitas hasil pertanian diperlukan upaya memacu dan mempertahankan produktivitas dan kualitas hasil pertanian dengan tingkat efisiensi penggunaan faktor-faktor produksi dan penggunaan bahan organik ramah lingkungan untuk mengembalikan kesuburan tanah serta kelestarian lingkungan.

Berbagai faktor diduga yang dapat menyebabkan pelandaian produktivitas, tetapi masih perlu penelitian lebih mendalam. Untuk sementara diduga kuat berkaitan dengan menurunnya efisiensi penggunaan pupuk. Dimana kenaikan produksi persatuan luas tidak sebanding dengan pupuk yang diberikan, selain itu sistem pertanian organik masih diabaikan sehingga turut andil terhadap produktivitas dan penurunan kualitas hasil pertanian terutama padi.

Agar masyarakat tani percaya bahwa sistem pertanian organik dapat memberikan keuntungan baik produktivitas pertanian maupun produktivitas lahan perlu dilakukan penyadaran terlebih dahulu. Tumbuhnya kesadaran masyarakat, akan menumbuhkan motivasi untuk mengadopsi teknologi pengelolaan lahan dengan sistem organik atau cara alami. Tumbuhnya motivasi instrinsik dipengaruhi oleh dorongan yang berasal 
dari dalam dirinya, misalnya ingin memenuhi kebutuhan pokok hidupnya, antara lain: sandang, pangan, papan, pendidikan dan kesehatan (Sianturi dalam Sutrisno. 2010). Motivasi ekstrinsik dipengaruhi untuk mendapatkan sesuatu yang lebih baik, misalnya mendapat hasil usaha yang lebih besar, dapat berkumpul dengan masyarakat yang lainnya, dan memperoleh status dalam kehidupannya.

Peran aktif dari Penyuluh Pertanian, tokoh masyarakat, pemerintah, pemimpin lokal, swasta atau pengusaha dan tingkat ketentuan dari sifat teknologi pertanian organik dapat menumbuhkan motivasi baik secara instrinsik maupun ekstrinsik. Tumbuhnya motivasi masyarakat baik secara intrinsik maupun ekstrinsik, yang didorong oleh peran aktif dari para pihak yang berkompeten dan sifat kelenturan dari teknologi organik pada tanaman padi, dapat mempengaruhi kinerja masyarakat (Robbins, 2003; Gibson et al, 1985). Meningkatnya kinerja masyarakat, mempunyai dampak yang baik dalam penerapan teknologi pertanian organik dan berpengaruh terhadap pendapatan masyartakat, dengan tumbuhnya motivasi tersebut yang diikuti dengan peningkatan kinerja dalam masyarakat diharapkan kebutuhan masyarakat akan terpenuhi. Terpenuhinya kebutuhan masyarakat dalam pengelolaan sistem pertanian organik pada tanaman padi yang selama ini belum dilakukan dengan baik walaupun sudah lama dikampanyekan oleh para penyuluh pertanian akan terwujud yang berbasis pada kepentingan masyarakat Kecamatan Sukolilo pada khususnya dan masyarakat Kabupaten Pati pada umumnya, bahkan sampai pada level nasional. Tulisan ini bertujuan untuk mengindentifikasi motivasi masyarakat tani dan strategi pengembangan tanamn padi organik di Kecamatan Sukolilo Kabupaten Pati.

\section{MOTIVASI MASYARAKAT TANI}

Motivasi, menurut Kamus Besar bahasa Indonesia adalah dorongan yang timbul pada diri seseorang, secara sadar/tidak sadar untuk melakukan sesuatu tindakan dengan tujuan tertentu. Usaha yang dapat menyebabkan, seseorang/kelompok orang tertentu tergerak, melakukan sesuatu karena ingin mencapai tujuan yang dikehendakinya atau mendapat kepuasan dengan perbuatannya (Depdikbud, 1997).

Berikutnya, pengertian motivasi berasal dari bahasa latin movere yang berarti dorongan atau menggerakkan. Dalam kehidupan, motivasi memiliki peranan sangat penting, karena motivasi yang menyebabkan, menyalurkan, dan mendukung perilaku manusia, sehingga mau bekerja giat dan antusias mencapai hasil yang optimal. Motivasi memberikan kekuatan-kekuatan untuk bekerja dalam diri seseorang untuk memulai dan mengarahkan perilaku secara terus menerus (Gibson et al, 1985). Menurut Gibson et al, (1985) dan Robbins (2006) pengertian motivasi mempunyai tiga hal penting yaitu: 1) Arah perilaku untuk mencapai tujuan yang akan dicapai; 2) Kekuatan respon atau usaha untuk melakukan sesuatu, dan 3) Kelangsungan berperilaku atau konsistensi.

Robbins (2003), menyebutkan bahwa tiga faktor yang memotivasi hubungan sasaran kinerja adalah: komitmen sasaran, tingkat keefektifan diri yang memadai, dan budaya kerja yang berlaku secara menyeluruh. Sejalan dengan Edwin Locke, Victor Vroom (Robbins, 2003) menyebutkan bahwa hubungan kinerja pada individu didorong oleh pengharapan individu tersebut untuk dapat memenuhi kebutuhannya secara pribadi dan dapat menumbuhkan potensi daya tarik imbalan bagi yang 
bersangkutan, imbalan atau insentif yang diterima individu, bukan hanya yang bermanfaat materi saja, tetapi lebih diutamakan yang berbentuk non materi sebagai penghargaan. Penghargaan non materi dapat meningkatkan motivasi individu bekerja lebih keras dan sungguh-sungguh.

Tumbuhnya motivasi masyarakat tani dalam mengelola lahan dengan sistem pertanian organik perlu diberikan penguatan. Penguatan ini dilakukan agar masyarakat tidak merasa putus asa jika mengalami kegagalan. Dengan penguatan atau rangsangan yang positif, masyarakat akan mengubah perilaku secara kontinyu atau terus menerus. Menurut Skinner (Gibson et al, 1985) menyebutkan bahwa penguatan positif (positive reinforcer) akan meningkatkan tanggapan yang cenderung untuk mengulangi perilaku yang telah dilakukan sebelumnya. Oleh karena itu, perubahan perilaku yang dilakukan masyarakat dalam mengelola lahan dalam sistem pertanian organik dan telah memberikan hasil yang nyata dapat memicu untuk melakukan pengelolaan secara terus menerus dan dapat menularkan kepada anggota masyarakat lainnya.

Masyarakat disekitar wilayah Kecamatan Sukolilo yang didukung oleh lahan sawah berpengairan teknis karena mendapat suplai air pengairan dari Waduk Kedungombo Kabupaten Boyolali Provinsi Jawa Tengah, memberi keuntungan tersendiri bagi masyarakatnya yang cenderung memanfaatkan pola tanam padi-padipalawija. Perkembangan pola tanam tersebut merupakan kegiatan yang menguntungkan bagi masyarakat di Kecamatan Sukolilo dan sekitarnya terutama petani jika dibanding 15 tahun yang lalu karena sebagian besar masyarakatnya adalah petani.

Kecamatan Sukolilo sebagai obyek pengamatan memiliki 16 Desa dengan jumlah Kepala keluarga (KK) mencapai $30.220(32,04 \%)$ dari jumlah penduduk sebanyak 94.321 jiwa. Ini artinya bahwa penduduk Kecamatan Sukolilo dominan pada profesi sebagai petani dan hal ini juga didukung oleh potensi lahan yang dimiliki. Desa Sukolilo sendiri jumlah KK petani mencapai tertinggi yaitu sebanyak 5.891 (19,49\%), disusul Desa Kedung Winong sebanyak 3.027 $(10,07 \%)$ dan Desa Prawoto sebanyak $3.019(9,99 \%)$ KK tani. Sementara itu KK tani terkecil dicapai Desa Cengkal Sewu yaitu $272 \quad(09,00 \%)$ KK tani disusul Desa Porangparing sebanyak 460 $(1,52 \%)$ KK tani, Desa Kasiyan 514 $(1,70 \%)$ KK tani dan Desa Pakem sebanyak $587(1,94 \%)$ KK tani. KK tani yang terkecil tersebut ada indikasi karena daerahnya sering banjir seperti Desa Kasiyan dan Desa Cengkalsewu. Sementara Desa Porangparing dan Pakem, kondisinya didaerah pegunungan Kendeng Utara atau lahan kering sehingga wajar jika KK taninya kecil (BPP Kec. Sukolilo, 2010).

Kondisi masyarakat tersebut, memiliki potensi untuk diarahkan ke pengelolaan pertanian secara ramah lingkungan (pertanian organik) yang memperhatikan lingkungan karena didukung oleh pengairan teknis, terutama desa-desa yang memiliki pengairan teknis. Potensi lahan sawah berpengairan teknis di Kecamatan Sukolilo mencapai $5.359 \mathrm{Ha}(15,86 \%)$. Hal ini suatu potensi yang sangat menggembirakan bagi petani untuk mengelola lahan dengan baik, karena mendapat suplay pengairan dari Waduk Kedungombo yang tidak dimiliki oleh Kecamatan lain kecuali sebagian Kecamatan Kayen.

Peran Penyuluh Pertanian dalam memotivasi pengelolaan sistem pertanian organik sangat diperlukan. Mardikanto (2003) untuk dapat melakukan tugas dengan baik, penyuluh harus menguasai substansi teknis, sistem 
sosial masyarakat setempat, definisi dan falsafah penyuluhan dengan baik. Penyuluhan menurut Kartasapoetra (1987) merupakan suatu ilmu sosial yang mempelajari sistem dan proses penyuluhan pada individu dan masyarakat agar dengan terwujudnya perubahan tersebut dapat tercapai apa yang diharapkan sesuai dengan pola atau dengan rencananya. Dengan demikian, arti penyuluhan adalah suatu usaha atau upaya mengubah perilaku petani dan keluarganya, agar mereka mengetahui dan mempunyai kemampuan serta mampu memecahkan masalahnya sendiri dalam usaha atau kegiatan-kegiatan meningkatkan hasil usahanya dan tingkat kehidupannya. Pendapat tersebut dikuatkan oleh Samsudin (1977) bahwa penyuluhan pertanian adalah suatu cara atau usaha pendidikan yang bersifat non formal untuk para petani dan keluarganya di pedesaan.

Sikap keterbukaan para petani hanya dapat ditimbulkan karena pendekatan-pendekatan dalam lingkup penyuluhan (bukan dengan cara paksaan). Keterbukaan dalam menerima pengetahuan dan teknologi usaha pertanian yang baik akan memudahkan penerimaan penyuluhan berikutnya yang kontinuitas, bahkan keterbukaan akan menjadikan penyuluhan pertanian sebagai kebutuhan mereka karena hasrat para petani beserta keluarganya sangat mendambakan pola hidup yang lebih baik dalam kebahagian dan kesejahteraan.

Untuk membantu petani dalam mengelola lahan khususnya dengan menggunakan sistem pertanian organik sangat membutuhkan peran penyuluh. Peran yang dibutuhkan oleh petani antara lain: informasi-informasi yang dibutuhkan oleh para petani seperti harga pasar, inovasi baru, penggunaan teknologi lokal, dan memfasilitasi petani dengan pihak-pihak yang terkait. Agar peran Penyuluh dapat optimal dan dapat dirasakan oleh petani, menurut Najiyati et al, (2005) antara lain sebagai: motivator, fasilitator, dinamisator dan isnpirator, konselor, mediator dan bantuan advokasi.

\section{PENGEMBANGAN PADI ORGANIK}

Kegiatan pengembangan sistem pertanian organik di Kabupaten Pati secara umum tidak terlepas dari kerangka kebijakan pemerintah pada sektor pertanian. Oleh karena itu, kegiatan pengembangan padi organik harus memiliki visi membangun kekuatan pertanian Indonesia berwawasan lingkungan sebagai basis kemandirian bangsa menghadapi era pasar bebas. Misi yang harus diemban juga hendaknya mampu membangun posisi tawar masyarakat tani dalam pengembangan kegiatan pertanian melalui pendekatan berbasis masyarakat, sehingga pengembangan sektor pertanian mampu memenuhi keinginan pasar internasional dalam perencanaan program yang terarah, terkendali dan berkelanjutan.

Kesesuaian lahan pertanian merupakan suatu syarat kemampuan lahan dalam mendukung pertumbuhan tanaman padi. Faktor-faktor yang mempengaruhi kesesuaian lahan pertanian ini terdiri dari tingkat kesuburan tanah, tekstur, struktur tanah, topografi/kemiringan tanah, unsur-unsur penghambat pertumbuhan tanaman (seperti $\mathrm{FeS}_{2}$, gambut, dll), drainase, irigasi, dll. Kesesuaian lahan juga dapat diartikan sebagai penekanan prasyarat kemampuan lahan dalam menyediakan semua kebutuhan unsur hara dan air serta faktor-faktor lain yang kondusif bagi pertumbuhan tanaman pertanian khususnya tanaman padi.

Kajian sementara lahan sawah di Kecamatan Sukolilo yang berpengairan 
teknis memiliki tingkat kesesuaian lahan S1 dan S2, artinya bahwa lahan tersebut memiliki potensi untuk pengembangan budidaya tanaman padi sisten pertanian organik yang sangat tinggi. Kondisi eksisting lahan pertanian organik di Kecamatan Sukolilo terdiri dari lahan padi organik aktual dan lahan padi organik potensial.

a. Lahan pertanian padi organik aktual adalah lahan pertanian yang dalam budidaya tanaman padinya telah melakukan proses budidaya padi secara organik. Budidaya padi organik di Kecamatan Sukolilo masih belum berkembang dengan baik bahkan belum ada yang memulai tanam padi organik. Untuk itu perlu dipacu dan dimotivasi agar para petani mau dan menyadari bahwa pertanian padi organik sudah waktunya untuk dikembangkan di Kecamatan Sukolilo. Adanya budidaya sistem pertanian organik di Kecamatan Sukolilo bisa diawali dari kondisi petani yang dihadapkan pada mahalnya sarana produksi berupa pupuk dan obat-obatan kimia serta kesulitan mencarinya ditambah daya beli masyarakat tani rendah. Kondisi demikian menyebabkan petani mulai berfikir untuk beralih kembali dengan menggunakan pupuk organik. Oleh karena itu, sebenarnya budidaya pertanian padi organik yang ada di Kecamatan Sukolilo sudah ada sejak dulu walaupun yang dilakukan petani masih bersifat semi organik. Pada dasarnya ada tiga penyebab adanya budidaya sistem pertanian padi organik di Kecamatan Sukolilo yaitu: 1) Petani sudah sejak dulu melakukan budidaya padi tanpa harus melakukan pemupukan dari pabrik dan pestisida kimia, 2) Petani merasa mengalami kesulitan untuk mendapatkan pupuk kimia dan pestisida. Kesulitan tersebut dapat berupa harganya yang tinggi dll, dan 3) Adanya kaji terap budidaya padi organik dan pendampingan dalam pengembangannya.

b. Lahan pertanian organik potensial adalah lahan pertanian yang pada kondisi sekarang belum dilakukan teknologi budidaya pertanian padi organik tetapi dilihat dari lahan, memenuhi syarat untuk pengembangan pertanian padi organik. Karakteristik lahan potensial ini antara lain: 1) Memiliki pengairan teknis yang dapat mencukupi kebutuhan hidup tanaman padi, 2) Lahan sangat subur dan cocok untuk pengembangan padi, 3) Belum adanya aktivitas penggunaan pupuk kimia sintetis dan pestisida kimia yang intensif, 4) Lahan merupakan suatu hamparan yang jauh dari aktivitas permukiman padat, 5) Jauh dari kegiatan industri yang menghasilkan limbah kimia.

Dalam pengembangan pertanian organik diperlukan beberapa aspek antara lain:

\section{Aspek Sosial Budaya}

Ada dua teori yang mendasari aspek sosial budaya yaitu: Pertama, Teori Fungsionalisme, struktural teori ini lebih menekankan pada keteraturan/order, mengabaikan konflik dan perubahan-perubahan dalam masyarakat. Konsep utamanya adalah fungsi, disfungsi, fungsi laten, fungsi manifest dan keseimbangan/equilibrium. Masyarakat menurut teori ini merupakan suatu sistem sosial yang terdiri atas bagian/elemen yang saling berkaitan dan menyatu dalam keseimbangan. Perubahan yang terjadi pada satu bagian akan membawa perubahan pula terhadap bagian yang lain. Asumsi dasarnya adalah bahwa setiap struktur dalam sistem sosial fungsional terhadap yang lain. Sebaliknya kalau tidak fungsional 
maka struktur tidak akan ada atau hilang dengan sendirinya. Salah satu tokohnya adalah Robert K.Merton berpendapat bahwa objek analisa sosiologi adalah fakta sosial seperti peranan sosial, polapola institusional, proses sosial, organisasi kelompok, pengendalian sosial, dll. Penganut teori fungsional ini memang memandang segala pranata sosial yang ada dalam suatu masyarakat tertentu serba fungsional dalam artian positif dan negatif. Satu hal yang dapat disimpulkan adalah bahwa masyarakat senantiasa berada dalam keadaan berubah secara berangsur-angsur dengan tetap memelihara keseimbangan. Setiap peristiwa dan setiap struktur yang ada fungsional bagi sistem sosial itu. Masyarakat dilihat dalam kondisi dinamika dalam keseimbangan.

Kedua, teori konflik, teori ini dibangun dalam rangka menentang langsung terhadap teori fungsionalisme struktural. Tokoh utama teori ini adalah Ralp Dahrendorf. Teori ini bertentangan dengan fungsionalisme struktural yaitu masyarakat senantiasa berada dalam proses perubahan yang di tandai pertentangan yang terus menerus di antara unsur-unsurnya. Teori ini menilai bahwa keteraturan yang terdapat dalam masyarakat hanyalah disebabkan karena adanya pemaksaan/tekanan kekuasaan dari atas oleh golongan yang berkuasa. Konsep teori ini adalah wewenang dan posisi. Keduanya merupakan fakta sosial. Dahrendorf berpendapat bahwa konsepkonsep seperti kepentingan nyata dan kepentingan laten, kelompok kepentingan dan kelompok semu, posisi dan wewenang merupakan unsur-unsur dasar untuk dapat menerangkan bentuk-bentuk dari konflik. Kegiatan pengembangan padi organik di Kecamatan Sukolilo secara umum tidak terlepas dari kerangka kebijakan pemerintah pada sektor pertanian. Oleh karena itu, kegiatan pengembangan padi organik harus memiliki visi membangun kekuatan pertanian berwawasan lingkungan sebagai basis kemandirian dalam menghadapi era pasar bebas.

Misi yang harus diemban juga hendaknya mampu membangun posisi tawar masyarakat tani dalam pengembangan kegiatan pertanian melalui pendekatan berbasis masyarakat, sehingga pengembangan sektor pertanian mampu memenuhi keinginan pasar dalam perencanaan program yang terarah, terkendali dan berkelanjutan.

Dengan latar belakang terjadi surplus produksi padi dibanding tingkat konsumsi masyarakat Kecamatan Sukolilo, maka rencana pengalihan dari teknologi budidaya padi konvensional yang menggunakan pupuk sintentis dan pestisida kimia ke teknologi budaya pertanian organik yang menggunakan bahan-bahan alami adalah sangat tepat. Langkah yang diambil tersebut tepat karena image pasar produk pertanian dunia sekarang menginginkan produkproduk alami (organik), sehingga kelebihan (surplus) produksi padi yang merupakan salah satu faktor penyebab turunnya harga dasar gabah tersebut dapat dialihkan menjadi produk yang memiliki nilai tambah dan diminati oleh pasar dunia.

Karakteristik petani di Kabupaten Pati pada umumnya dan Kecamatan Sukolilo pada khususnya, bersifat subsisten dengan kepemilikan lahan yang sempit menjadikan petani sangat menggantungkan hidupnya terhadap lahan yang dimilikinya. Sifat ketergantungan yang kuat terhadap lahan tersebut menyebabkan petani kurang kreatif, monoton dan cenderung protektif. Sikap yang demikian lebih mencerminkan pada ketakutan petani 
akan resiko kegagalan panen yang akan dihadapi jika mereka mencoba suatu yang baru (pertanian organik). Dalam kondisi yang demikian program pemerintah sekalipun konseptualnya baik menjadi kurang bisa diterima oleh petani jika dipaksakan pelaksanannya oleh petani, maka akan dilaksanakan dengan setengah hati. Untuk merencanakan program sistem pertanian organik, perlu melakukan berbagai pendekatan antara lain:

a. Pendekatan program, harus bersifat bottom up (perencanaan dari bawah), artinya dalam perenanaan program harus menyentuh substansi dasar permasalahan petani. Petani diberikan keleluasaan untuk menentukan kebutuhan apa yang dirasakan paling mendasar. Bersama-sama dengan pemerintah memilih skala prioritas dan mana yang merupakan kebutuhan riil dan mana yang hanya sebatas keinginan. Program pengembangan padi organik harus terintegrasi lintas sektoral, artinya dalam merencanakan program harus mengikut sertakan semua pihak yang terkait (stakeholders), sehingga terjadi keselarasan program saling mendukung dalam mencapai satu tujuan. Tidak perlu terjadi dalam satu obyek pembangunan (masyarakat tani) yang sama, namun pendekatan yang dipakai berbeda-beda sehingga akan membingungkan masyarakat tani.

b. Pendekatan kelembagaan, lemahnya kelembagaan ditingkat petani mengakibatkan petani melakukan kegiatan secara sendiri-sendiri. Kondisi semacam ini kurang menguntungkan bagi petani karena rendahnya kemampuan petani dalam menguasai teknologi budidaya, pasar dan permodalan menjadi sangat terbatas. Oleh karena itu, perlu dibentuk suatu lembaga yang mampu dan mengakar pada petani sehingga dapat diterima oleh petani. Pembentukan lembaga (kelompok tani) harus dimulai dari inisiatif petani sendiri, baru kemudian pemerintah memfasilitasi dalam pembentukan kelompok tani sesuai dengan kultur daerah masing-masing. Kita tidak boleh mengulangi pendekatan lama yaitu bersifat top down yang pembentukan kelembagaan (kelompok tani) disetting oleh pemerintah dan dilembagakan secara nasional.

c. Sistem pendampingan, masyarakat petani kita masih bersifat tradisional, monoton dan protektif, maka diperlukan pendampingan dalam mengelola kelembagaan tani (kelompok tani) baik oleh para Penyuluh Pertanian maupun Lembaga Swadaya Masyarakat (LSM) yang credible dan peduli pada petani. Dengan pendampingan ini dapat memberikan motivasi, harapan dan keterikatan antar petani menjadi lebih kuat, sehingga mampu menumbuhkan kinerja aktivitas yang tinggi.

\section{Aspek Ekonomi}

Aspek ekonomi harus diperhatikan dalam pengembangan pertanian padi organik di Kabupaten Pati pada umumnya dan di kecamatan Sukolilo pada khususnya yang menekankan pada perolehan manfaat secara ekonomi bagi seluruh share holder dalam kegiatan tersebut. Manfaat secara ekonomis tidak hanya dirasakan oleh petani maupun pelaku pasar tetapi juga oleh pemerintah daerah yang memfasilitasi kegiatan tersebut. Maka dari itu pemerintah Kabupaten Pati dapat berinisitif untuk: 1) Menginfentarisasi (data base) potensi pertanian didaerahnya secara riil dan mampu mempresentasikan (kelayakan usaha) kepada pihak-pihak yang akan memfasilitasi pendanaan, 2) Mengajak 
pihak swasta pelaku pasar (buyers) untuk menampung hasil produksi pertanian padi organik, dengan harga produk yang proporsional dan memihak kepada petani, dan 3) Menjadi mediasi keterbatasan petani dalam mengakses dana karena persyaratan yang rumit bagi petani diperbankan.

Efisiensi usaha tani dapat diukur dengan cara menghitung efisiensi teknis, efisiensi harga dan efisiensi ekonomis. Pengertian tentang efisiensi ini telah banyak dibahas diliteratur diantaranya Soekartawi (2002) dan Suratiyah (2006). Ketiga macam efisiensi ini penting untuk diketahui dan diraih oleh petani bila ia menginginkan keuntungan yang sebesarbesarnya. Umumnya memang petani tidak mempunyai catatan usaha tani (farm recording); sehingga sulit bagi petani untuk melakukan analisis usahataninya. Petani hanya mengingatingat cash flow yang mereka lakukan, walaupun sebenarnya ingatan itu tidak terlalu jelek, karena mereka masih ingat bila ditanya tentang berapa output yang mereka peroleh dan berapa input yang mereka gunakan.

Perlunya analisis usaha tani memang bukan untuk kepentingan petani saja tetapi untuk para penyuluh pertanian. Dalam melakukan analisis usaha tani ini, seseorang dapat melakukannya menurut kepentingan untuk apa analisis usaha tani yang dilakukannya. Dalam banyak pengalaman analisis usaha tani yang dilakukan oleh petani atau produsen memang dimaksudkan untuk mengetahui tujuan atau meneliti (Soekartawi dkk, 1990): 1) Keunggulan komparatif (comparative advantage), 2) Kenaikan hasil yang semakin menurun (law of diminishing), 3) Substitusi (substitution effect), 4) Pengeluaran biaya usahatani (farm expenditure), 5) Biaya yang diluangkan (opportunity), 6) Pemilikan cabang usaha (macam tanaman lain apa yang dapat diusahakan), dan 7) Bakutimbang tujuan (goal trade-off).

Usaha tani berskala luas pada umumnya bermodal besar, berteknologi tinggi, manajemennya modern, lebih bersifat komersial, dan sebaliknya usaha tani skala kecil umumnya bermodal paspasan, teknologinya tradisonal, lebih bersifat usaha tani sederhana dan sifat usahanya subsisten, serta lebih bersifat untuk memenuhi kebutuhan konsumsi sendiri dalam kehidupan sehari-hari.

Pada dasarnya usaha tani berkembang terus dari awal hanya bertujuan menghasilkan bahan pangan untuk kebutuhan keluarga sehingga hanya merupakan usahatani-swasembada atau subsistence. Oleh karena itu, sistem pengelolaan yang lebih baik maka dihasilkan produk berlebih dan dapat dipasarkan sehingga bercorak usahataniswasembada keuangan. Pada akhirnya karena berorentasi pada pasar maka menjadi usahatani niaga (Suratiyah, 2006).

\section{Aspek Teknologi}

Aspek efisiensi dan efektifitas dalam konteks teknologi modern adalah menjadi satu tujuan dalam pengembangan teknologinya, namun dengan berbagai dampak yang ditimbulkan dari hasil teknologi tersebut menjadikan manusia berfikir ulang, bahwa kecanggihan suatu teknologi tidak lagi hanya menekankan pada efisiensi dan efektifitas saja tetapi juga berkelangsungan alam sebagai wadah aktivitas manusia yang sangat diperlukan.

Maka dari itu program pengembangan pertanian padi organik di Kabupaten Pati harus menekankan penggunaan teknologi budidaya yang tidak menimbulkan degradasi lingkungan 
dan lebih jauh mampu meningkatkan daya dukung lingkungan yang lebih kondusif bagi pertumbuhan tanaman padi, utamanya.

Pada prinsipnya teknologi budidaya pertanian padi organik lebih menekankan pada pemanfaatan bahanbahan alami yang tersedia melimpah ruah disekitar petani untuk mendukung pertumbuhan tanaman tanpa menimbulkan efek negatif baik bagi lingkungan maupun tanaman itu sendiri, sehingga pemakaian bahan apapun harus mampu melindungi alam, petani maupun produk yang dihasilkan dalam ekosistem pertanian tersebut.

Di negara maju ilmu pengetahuan dan teknologi (Iptek) telah menjadi suatu kesatuan dengan proses pembangunan dihampir segala bidang. Berbagai macam inovasi dan terobosan ilmu pengetahuan dan teknologi, termasuk di bidang produksi pertanian, hampir menjadi agenda rutin para ilmuwan dan anggota masyarakat lainnya. Persoalan di negara ketiga tak terkecuali Indonesia tingkat aplikasi dan penguasaan teknologi bidang pertanian masih cukup rendah. Anggaran dana penelitian untuk sektor pertanian masih jauh dibawah $1 \%$ dari Produk Domestik Bruto (PDB).

Dunia ketiga masih saja menghadapi kendala pelembagaan dan penerapan teknologi baru tersebut dikalangan para petani. Akibatnya sosialisasi hasil penelitian dan pengembangan teknologi pertanian menghadapi kendala kelembagaan, karena misalnya jaringan kerja antara peneliti dan ilmuwan tidak sebaik yang diharapkan. Dalam bahasa Douglas North, penerima hadiah nobel ekonomi tahun 1993, penciptaan insentif bagi masyarakat untuk melalukan investasi pada teknologi yang lebih efisiens amatlah penting, dan perlu lebih inheren tercantum dalam kelembagaan yang ada.
Batasan teknologi hanya dimaksudkan sebagai seperangkat alat, pengetahuan manusia dan kelembagaan sosial ekonomi untuk melaksanakan suatu ikhtiar atau usaha untuk menghasilkan sesuatu yang lebih baik. Dalam ekonomi produksi pertanian, teknologi adalah suatu cara, mekanisme dan proses produksi untuk melakukan kombinasi faktor-faktor produksi (input) dalam menghasilkan sesuatu produk (output). Perubahan teknologi dengan sendirinya dapat diartikan sebagai perubahan cara mengkombinasikan faktor produksi tadi. Sementara itu, produktivitas dimaksudkan sebagai suatu ukuran efisiensi yang berupa rasio produk dengan faktor produksi tertentu. Inovasi baru atau perubahan teknologi umumnya mampu menaikkan tingkat produksi sekaligus produktivitasnya.

Dalam bidang produksi pertanian terdapat dua jenis teknologi: teknologi mekanis untuk "menghemat tenaga kerja" dan teknologi bio-kimia untuk "menghemat tanah". Teknologi mekanis sengaja dirancang untuk mensubstitusi (mengganti) faktor produksi tenaga kerja dengan mesin. Pada kondisi tertentu, tenaga kerja dapat dikatakan mampu mensubstitusi (mengganti) faktor tenaga kerja dengan mesin. Pada kondisi tertentu, tenaga kerja dapat dikatakan mampu mensubstitusi lahan karena semakin hari produktivitas tenaga kerja umumnya makin meningkat, atau dengan kata lain tenaga kerja mampu mengolah lahan lebih luas dibandingkan sebelumnya. Sedangkan teknologi biologis dan kimia tercipta untuk mengganti kelangkaan sumber daya lahan dengan pupuk dan benih unggul. Jadi "perang" inovasi baru dibidang produksi pertanian sering terfokus pada jenis teknologi yang layak dikembangkan pada keadaan dan kandungan sumber daya tertentu. 
Salah satu perubahan yang paling fundamental dalam industri pertanian adalah penggantian tenaga kerja manusia dan hewan dengan tenaga kerja mesin. Mekanisasi mampu meningkatkan hasil per unit input tenaga kerja dan menurunkan harga jual pangan per satuan. Namun demikian mekanisasi dibidang pertanian juga banyak menimbulkan akibat buruk, antara lain hilangnya kesempatan kerja, terciptanya ketergantungan pada energi minyak bumi, diperlukan modal yang lebih besar, dan tersentralisasinya teknologi pada usahatani berskala besar (Salikin, 2003).

Penggunaan mesin-mesin berat di bidang pertanian juga telah menimbulkan masalah tersendiri berkaitan dengan tingkat kesuburan tanah. Pemadatan struktur tanah dan rusaknya saluran air akan menurunkan daya serap tanah dan meningkatnya erosi. Pemadatan struktur tanah menyebabkan tanah sulit dibajak atau dicangkul dan menghambat proses perembesan air serta mengganggu proses pertumbuhan dan perkembangan sistem perakaran tanaman.

Kemajuan dan rekayasa bioteknologi sangat memungkinkan penemuan baru. Namun kecanggihan ilmu atau teknologi yang tidak dilandasi oleh etika, norma, dan agama akan sangat membahayakan eksistensi manusia sebagai makluk ciptaan Tuhan. Sikap paling bijak adalah tetap waspada agar manusia tidak pongah, arogan, dan menentang kodrat dengan temuantemuannya (Salikin, 2003).

\section{Aspek Kebijakan}

Banyak kajian dalam berbagai literatur menunjukkan bahwa ada hubungan interdepensi yang kuat antara lingkungan dengan pertanian. Ada beberapa kebijakan pembangunan pertanian berkelanjutan yang dapat dipilih, dan hal ini sangat tergantung pada pertimbangan bobot permasalahan, situasi, dan kondisi serta aspek lain. Menurut Young dan Burton (1992); pada hakekatnya kebijakan pembangunan pertanian yang berkelanjurtan adalah memformulasikan persoalan kerusakan lingkungan dan kemunduran sumberdaya yang mengakibatkan biaya sosial atau eksternalitas dalam kebijakan pertanian; dan diiternalisasikan dalam kebijakan ekonomi.

Kebijakan adalah prinsip atau cara bertindak yang dipilih untuk mengarahkan pengambilan keputusan. Menurut Ealau dan Pewitt (1973), kebijakan adalah sebuah ketetapan yang berlaku yang dicirikan oleh perilaku yang konsisten dan berulang, baik dari yang membuatnya maupun yang mentaatinya (yang terkena kebijakan itu). Titmuss (1974) mendefinisikan kebijakan sebagai prinsip-prinsip yang mengatur tindakan yang diarahkan kepada tujuan-tujuan tertentu. Kebijakan, menurut Titmuss, senantiasa berorientasi kepada masalah (problem-oriented) dan berorientasi kepada tindakan (action-oriented) dengan demikian dapat dinyatakan bahwa kebijakan adalah suatu ketetapan yang memuat prinsip-prinsip untuk mengarahkan cara-cara bertindak yang dibuat secara terencana dan konsisten dalam mencapai tujuan tertentu (Edi Suharto, 2008).

Dalam kaitannya dengan kebijakan sosial, maka kata sosial dapat diartikan baik secara generik atau luas maupun spesifik. Secara generik, kata sosial menunjuk pada pengertian umum mengenai bidang-bidang atau sektorsektor pembangunan yang menyangkut aspek manusia dalam konteks masyarakat atau kolektifitas. Istilah sosial dalam pengertian ini mencakup antara lain bidang pendidikan, kesehatan, politik, 
hukum, budaya, atau pertanian. Dalam arti spesifik atau sempit, kata sosial menyangkut sektor kesejahteraan sosial sebagai suatu bidang atau bagian dari pembangunan sosial atau kesejahteraan rakyat yang bertujuan untuk meningkatkan kualitas kehidupan manusia, terutama mereka yang dikategorikan sebagai kelompok yang tidak beruntung (disadvantaged group) dan kelompok rentan (vulnerable group). Kata sosial di sini menyangkut programprogram dan atau pelayanan-pelayanan sosial untuk mengatasi masalah-masalah sosial, seperti kemiskinan, ketelantaran, ketidak berfungsian fisik dan psikis, tuna sosial dan tuna susila, kenakalan remaja. (Edi Suharto, 2008)

Komitmen pemerintah Kabupaten Pati untuk mendukung pertanian padi organik antara lain dapat diwujudkan dalam bentuk: 1) Agenda pembangunan pertanian yang dibuat oleh pemerintah Kabupaten Pati harus mencerminkan satu kesatuan pemahaman akan kebutuhan riil dimasyarakat, 2) Program yang disusun oleh pemerintah Kabupaten Pati harus berkesinambungan dan berkelanjutan tidak berhenti oleh batasan tahun anggaran atau batasan proyek, 3) Harus ada peraturan daerah yang melindungi/memproteksi lahan dan petani organik dari kegiatan yang akan mengganggu keberlanjutan program pengembangan padi organik, 4) Pemerintah daerah mengalokasikan dana untuk pengkajian, petak percontohan pertanian padi organik sampai dengan petak pengembangan pertanian padi organik yang sudah komersial yaitu dengan kualitas, kuantitas dan kontinuitas produk yang terkontrol untuk kebutuhan ekspor.

\section{KESIMPULAN}

1. Tumbuhnya motivasi masyarakat tani dalam mengelola lahan dengan sistem pertanian organik perlu diberikan penguatan. Penguatan ini dilakukan agar masyarakat tidak merasa putus asa jika mengalami kegagalan. Dengan penguatan atau rangsangan yang positif, masyarakat akan mengubah perilaku secara kontinyu atau terus menerus.

2. Kegiatan pengembangan sistem pertanian organik di Kabupaten Pati secara umum tidak terlepas dari kerangka kebijakan pemerintah pada sektor pertanian. Oleh karena itu, kegiatan pengembangan padi organik harus memiliki visi membangun kekuatan pertanian Indonesia berwawasan lingkungan sebagai basis kemandirian bangsa menghadapi era pasar bebas. Misi yang harus diemban juga hendaknya mampu membangun posisi tawar masyarakat tani dalam pengembangan kegiatan pertanian melalui pendekatan berbasis masyarakat, sehingga pengembangan sektor pertanian mampu memenuhi keinginan pasar internasional dalam perencanaan program yang terarah, terkendali dan berkelanjutan.

\section{DAFTAR PUSTAKA}

\section{Balai Penyuluh Pertanian Kecamatan Sukolilo. 2010. Program Penyuluhan Pertanian. Pati}

Badan Pusat Statistik Kabupaten Pati. 2014. Pati dalam Angka Tahun 2013. Pati.

Departemen Pendidikan dan Kebudayaan. 1997. Kamus Besar Bahasa Indonesia, Edisi kedua. Jakarta : Balai Pustaka. 
Ealau dan Pewitt, 1973. Kebijakan

Publik. Jakarta : Handal Niaga Pustaka

Edi Suharto. 2008. Membangun Masyarakat Memberdayakan Rakyat. Bandung : Refika Aditama

Gibson, James L., J. M. Ivancevich, J. H. Donnelly $\mathrm{Jr}$ and R. Konopaske. 1985. Organizations, Behavior, Structure, Processes. Fourteenth Edition. New York : McGraw-Hill Companies Inc.

Kartasapoetra. 1987. Teknologi

Konservasi Tanah dan Air.

Jakarta : Rineka Cipta.

Mardikanto, T. 2003. Penyuluhan

Pembangunan Pertanian.

Surakarta : Universitas Sebelas

Maret Press.

Najiyati, S., L. Muslihat, dan I.N.N.

Suryadiputra. 2005. Panduan

Pengelolaan Lahan Gambut untuk

Pertanian Berkelanjutan. Project

Climate Change, Forests and

Peatlands in Indonesia. Bogor :

Wetlands International-Indonesia

Programme and Wildlife Habitat Canada.

Robbins, Stephen P. 2003. Perilaku Organisasi. Edisi 10. Jakarta : PT. Salemba Empat.

Salikin, A. Karwan. 2003. Sistem Pertanian Berkelanjutan.

Yogyakarta : Kanisius.

Samsudin, U. 1977. Dasar-dasar Penyuluhan dan Modernisasi. Bandung : Bina Cipta.
Soekartawi. 2002. Analisis Usahatani. Jakarta : Universitas Indonesia Press.

Sumarlan. 2011. Peningkatan Kinerja Petani sekitar hutan dalam penerapan sistem agroindustri dilahan kritis pegunungan kendeng Pati. Rencana Penelitian Desertasi. Bogor : Institut Pertanian Bogor.

Suratiyah, Ken. 2006. Ilmu Usahatani. Jakarta : Penebar Swadaya.

Sutrisno. 2009. Tingkat Produktivitas Padi di Kabupaten Pati. Laporan Penelitian. Kantor Penelitian dan Pengembangan. Pati. . 2010. Pengelolaan Pertanian Organik. Pati : CV. Mufidah SPG.

Titmuss, 1974. Social Policy. Jakarta: Handal Niaga Pustaka

Young, T. And M.P. Burton. 1992. Agricultural Sustainability: Definition and Implication for Agricultural and Trade Policy. Rome : FAO-UN.

\section{BIODATA}

Ir. Sutrisno, MM lahir 12 Januari 1956 di kota Kudus Provinsi Jawa Tengah. Pendidikan Magister Manajemen dari Universitas Muhamadiyah Surakarta. Saat ini menjadi Peneliti Madya Bidang Ekonomi Pertanian dan Kebijakan Pertanian di Kantor Penelitian dan Pengembangan Kabupaten Pati. 